\title{
Do Indonesian Laws and Policies on Covid-19 Countermeasures Action Reflect Legality?
}

\author{
I Made Arya Utama* \\ Faculty of Law, Udayana University, Bali-Indonesia
}

Article Received: 29th April 2020; Accepted: 26 ${ }^{\text {th }}$ July 2020; Published: $3^{\text {th }}$ July 2020

\begin{abstract}
Every citizen has the right to access the resources and health facilities, social security, health services, as well as attaining the highest degree of health. At the present, Covid-19 has become a global pandemic and has been declared a non-natural disaster, which could potentially be related to the citizen's right to health as regulated with statutory law. This article analyses the dynamics that reflect the legality of national statutory law in the response Covid-19 in Indonesia. This article is based on normative legal research using a statutory approach and conceptual approach. The study found that the right to health has properly been regulated in the Constitution as well as human rights and health-related legislations, reflecting the presence of the state to interfere with the health problems of its citizens. Besides, this study suggests that legal culture, as a component of legal system theory, remains an issue in the efforts of handling the pandemic. There is still a part of the society that is not able to readily and consciously participate and involve in the response to Covid-19 in Indonesia.
\end{abstract}

Keywords: Covid-19 Countermeasures Action; Legality; Legal Culture; Indonesia.

How to cite: Utama, I Made Arya. "Do Indonesian Laws and Policies on Covid-19 Countermeasures Action Reflect Legality?." Udayana Journal of Law and Culture 4, no. 2 (2020): 221-228. https://doi.org/https://doi.org/ 10.24843/UJLC.2020.v04.i02.p05

doi: https://doi.org/10.24843/UJLC.2020.v04.102.p05

\section{Introduction}

In terms of conceptual and ideology, Indonesia is classified as a State that tends to follow an open welfare state. ${ }^{1}$ The realization of the welfare state is marked by the active role of government and their presence to guarantee, protect, to respect, and to fulfill the citizen's constitutional rights. ${ }^{2}$

The right to health is one type of human rights or constitutional rights in the second generation of human rights. Furthermore, the right to health

* Email/Corresponding Author: Email: arya_utama@unud.ac.id

${ }^{1}$ See Alfitri, "Ideologi Welfare State dalam Dasar Negara Indonesia: Analisis Putusan Mahkamah Konstitusi Terkait Sistem Jaminan Sosial Nasional," Jurnal Konstitusi 9, no.3 (2012): 467- 470,

2 Irene Istiningsih Hadiprayitno, "Defensive enforcement: Human rights in Indonesia," Human Rights Review 11, no. 3 (2010): 378. 
in specific physical and spiritual prosperity as one type of basic human rights or constitutional rights requires an active role of government to guarantee, protect, respect and fulfill it. ${ }^{3}$ In the Indonesian Constitution, the right to health is specifically regulated in Article $28 \mathrm{H}$ (1), that stated: "Every person is entitled ... to acquire a good and healthy living environment as well as be entitled to obtain health care". ${ }^{4}$ It means that the right to health is considered as one of the constitutional rights that need an active role of government to implement the right to health. ${ }^{5}$

The continuing spread of Corona Virus Disease-19 (hereinafter referred to as Covid-19) in Indonesia forces the government to issue a series of policies in handling infectious diseases. In principle, the government is responsible for the implementation of health services as part of the implementation of good governance and the mandate of the constitution to ensure a decent life in a healthy environment and obtain health services as a consequence of achieving progress and social welfare. ${ }^{6}$ From an academic point of view, there is a concern about how the government ensures the implementation of the right to health, through strategic and tactical steps during this pandemic situation.

Almost all national agencies and sectoral ministries in Indonesia play a role in addressing pandemic-related problems. The first and most important one is the Ministry of Health. When the pandemic is declared potential to be spread internationally, the Ministry of Health in January 2020 adopted several preventing policies in the form of circulars to ensure the readiness of regional health departments, port health offices, Center for Environmental Health and Disease Control Engineering, and referral hospitals to anticipate the pandemic. ${ }^{7}$ The Ministry of Health has continuously issued a series of

3 Firdaus Firdaus, "Pemenuhan Hak atas Kesehatan bagi Penyandang Skizofrenia di Daerah Istimewa Yogyakarta”, Jurnal Ilmiah Kebijakan Hukum 10, no. 1 (2016): 92-93.

4 I Gede Yusa and Bagus Hermanto, "Implementasi Green Constitution di Indonesia: Jaminan Hak Konstitusional Pembangunan Lingkungan Hidup Berkelanjutan", Jurnal Konstitusi 15, No. 2 (2018): 313-314.

5 Made Adhitya Anggriawan Wisadha and Grita Anindarini Widyaningsih, "Human Rights and the Environmental Protection: The Naïveté in Environmental Culture" Udayana Journal of Law and Culture 2, no. 1 (2018): 76-77. doi: https: / / doi.org/ 10.24843/UJLC.2018. v02.i01.p04.

'Pocut Eliza, et.al., Laporan Akhir Kelompok Kerja Analisis Evaluasi Hukum mengenai Pemenuhan Hak Kesehatan (Jakarta: Pusat Analisis dan Evaluasi Hukum Nasional Badan Pembinaan Hukum Nasional Kementerian Hukum dan HAM RI, 2017), 216.

7 Circular of Director General of Disease Prevention and Control No. SR.03.04/II/55/2020 concerning Preparedness for the Spread of Pneumonia from the People's Republic of China to Indonesia, dated 6 January 2020; Circular of Director General of Disease Prevention and Control SR.02.02/II/270/2020 concerning Preparedness Guidelines for Coronavirus Novel Infection (2019-nCoV), dated 28 January 2020. Circular of Director General of Disease Prevention and Control HK.02.02 / II / 329/2020 concerning Increased Awareness of 2019-nCoV Infection as a World Public Health Emergency (KKMMD) / PHEIC, dated 31 January 2020; Circular of Director General of Health Services No. YR.01.02/111/0027/2020 concerning Hospital Preparedness in Handling Emerging Infectious Diseases, dated 7 January 2020 
regulations, circulars, guidelines, decrees, and regular public announcements. ${ }^{8}$ This includes the issuing of Guidelines for Prevention and Control of Covid-19, delivering the Self-isolation Protocol, ${ }^{9}$ organizing the means of public communication to informing the development of the pandemic, ${ }^{10}$ and appointed referral hospital in all provinces. ${ }^{11}$ Besides, the Minister of Health holds a strategic authority to approve a large scale social restriction to be established by regional governments in certain areas. ${ }^{12}$

The Ministry of Religious Affairs also plays a role in ensuring religious activities are not becoming the media of spreading the Covid-19. The Minister issued circular to manage activities in house of worship, that usually attended by many involve many peoples, are according to health protocol. ${ }^{13}$ The Ministry of Law and Human Rights also issued policies in the context of immigration that restricted the coming of international travelers from various suspected countries and areas. ${ }^{14}$

Since March 2020, medias mostly reported the role of the National Agency for Disaster Countermeasure (Badan Nasional Penanggulangan Bencana/BNPB) after the President of Indonesia appointed the Head of BNPB as the Chief of Task Force for the Acceleration of Covid-19 handling as well as determined the task force secretariat is at BNPB. ${ }^{15}$ In July 2020, the President conducted a restucturization. The taskforce was incorporated into a newly established Committee for the Handling of Covid-19 and National Economic Recovery in order to accelerate the handling of Corona Virus Disease 2019 (Covid-19) as well as recovery and national economic transformation. ${ }^{16}$ The creation of such committee was motivated by the fact, that the pandemic has had an impact on people's lives in social aspects,

8 The Latest is Decree of the Minister of Health of the Republic of Indonesia No. HK.01.07/ MENKES/413/2020 concerning Guidelines for Prevention and Control Coronavirus Disease 2019 (COVID-19)

${ }^{9}$ Circular of Minister of Health No. HK.02.01/Menkes/202/2020 concerning the SelfIsolation Protocol in Handling Corona Virus Diesease (Covid-19)

10 Circular Letter No. HK.02.01/Menkes/199/2020 concerning the Communication of Covid-19 Handling

11 Decree No. HK.01.07/Menkes/169/2020 concerning the Establishment of a Reference Hospital for the Prevention of Certain Emerging Infection Diseases.

${ }_{12}$ Article 2 of Government Regulation No. 21 of 2020 concerning Large-Scale Social Restrictions in the Framework of Accelerating Handling of Covid-19

13 Circular of Minister of Religious Affairs No: SE. 15 of 2020 Regarding Guidelines for the Management of Religious Activities in House of Worship in Realizing Productive Communities and Safe During the Pandemic Period.

${ }^{14}$ Regulation of Minister of Law and Human Rights No. 7 of 2020 concerning the Granting of Visa and Residence Permit in the Efforts of Preventing the Coronavirus Entry and Regulation of Minister of Law and Human Rights No. 11 of 2020 concerning Temporary Prohibition of Foreigners Entering the Territory of the Republic of Indonesia

${ }^{15}$ Article 7 and 8 of the Decree of the President of the Republic of Indonesia No.7 of 2020 concerning Task Force for the Acceleration of Covid-19 Handling

${ }^{16}$ Article 1 (1) of the of the Presidential Regulation of the Republic Of Indonesia No. 82 of 2020 concerning the Creation of Committee for the Handling of COVID-19 and National Economic Recovery 
economy, and well-being, and has been causing a decrease in various economic activities that endanger the national economy. ${ }^{17}$

This article is written to explore the meaning of the right to health as contained in, primarily, national legal instruments. It aims to assess the right to health in legal dogmatics and to analyze the legality of countermeasures action in Indonesia and the reflection of the right to health.

This article is qualified into normative legal research ${ }^{18}$ that views law as a prescriptive discipline ${ }^{19}$ and specifically focuses on the substance of the norms and system hierarchies of laws. The legal sources of this article were collected through the library research method while the normative analysis uses some approaches. The statue approach is used to examine both national and international legal instruments. The conceptual approach is related to the principle of constitutionalism in the context of the rule of law, the right to health, legality, and the politics of national law. The analysis is presented qualitatively by using prescriptive and argumentative techniques.

\section{Result and Discussion}

\subsection{Right to Health in Legal Dogmatics}

At the international level, the "right to health" is widely acknowledged as part of the second generation of human rights along with "economic social," "cultural rights," "labor rights," "right (to) health," "rights (to) education," and "socioeconomic rights," 20 as generally adopted in the International Covenant on Economic, Social and Cultural Rights (ICCPR). This second-generation human rights require institutional support from the state to be exercised independently and singular. ${ }^{21}$ The Limburg Principle on the Implementation of ICCPR developed a set of principles on obligations in relation to economic, social, and cultural rights. On the other hand, a comprehensive framework for understanding the legal nature of the norms was found in the ICCPR. ${ }^{22}$ It outlines that States parties must at all times

${ }^{17}$ Presidential Regulation of the Republic Of Indonesia No. 82 of 2020 concerning the Creation of Committee for the Handling of COVID-19 and National Economic Recovery, Consideratios $(\mathrm{a}$ ( and $(\mathrm{b})$

18 Depri Liber Sonata, "Metode Penelitian Hukum Normatif dan Empiris: Karakteristik Khas dari Metode Meneliti Hukum," Fiat Justisia: Jurnal Ilmu Hukum 8, No. 1(2014): 25-27.

${ }^{19}$ Karen Petroski, "Legal fictions and the Limits of Legal Language," International Journal of Law in Context 9, No. 4 (2013): 488.

20 Spasimir Domaradzki, Margaryta Khvostova, and David Pupovac, "Karel Vasak's "Generations of Rights and the Contemporary Human Rights Discourse," Human Rights Review 20 (2019): 436, 440.

${ }^{21}$ Adrian Vasile Cornescu, "The Generations Of Human's Rights”, Dny práva - 2009 Days of Law: the Conference Proceedings (2009)

${ }_{22}^{2}$ United Nations. Economic, Social and Cultural Rights Handbook for National Human Rights Institutions (New York and Geneva: United Nations Publication, 2005): 7. 
act in good faith to fulfill the obligations they have accepted under the ICCPR and have an obligation, regardless of the level of economic development, to ensure respect for minimum subsistence rights for all". ${ }^{23}$

At the national level, the right to health aspects can be assessed through some existing laws, regulations, and policies in Indonesia. In specific, the following analysis will assess the national policy direction, whether or not it conforms with international legal instruments or whether or not it can become a guideline for national health policy.

The right to health is currently a legitimate constitutional right. Historically, the general idea of human rights, including the right to health, was not included in the 1945 Constitution of the Republic of Indonesia, following the results of debates between Indonesia's founding fathers during the creating process. ${ }^{24}$ After the political reforms at the beginning of the millennium era, human rights were officially included as constitutional rights, as stipulated in Chapter XA. The right to health is explicitly mentioned in Article 28H paragraph (1), as follows, "every person shall have the right to live in physical and mental prosperity, to have a home and to enjoy a good and healthy environment, and shall have the right to obtain medical care." The content of the right to health is also implied in some constitutional provisions related to the Right to life, ${ }^{25}$ children's rights to live, to grow and to develop, ${ }^{26}$ and the right to access information, especially relating to health information. ${ }^{27}$

Article 28I (4) of the Indonesian Constitution makes clear that the protection, advancement, upholding, and fulfillment of human rights are the responsibility of the state, especially the government. The State obligation with regards to the fulfillment of the right to health is becoming part of the constitutional framework of social welfare. The Constitution stipulates that the state shall develop a system of social security for all people. ${ }^{28}$ Moreover, the State is responsible to provide sufficient medical and public service

23 United Nations Economic and Social Council UN doc. E/CN.4/1987/17, Annex, Limburg Principles on the Implementation of the International Covenant on Economic, Social, and Cultural Rights, para 7 and 65.

${ }^{24}$ See the views of Soekarno, Soepomo, Hatta, and M. Yamin in Saafroedin Bahar, Risalah Sidang BPUPKI dan PPKI (Jakarta: Sekretariat Negara, 1995), 37-38.

25 Article 28A of the 1945 Constitution of the Republic of Indonesia

${ }^{26}$ Ibid.

27 Ibid., Article 28F. See also Hernadi Affandi,"Implementasi Hak atas Kesehatan menurut Undang-undang Dasar 1945: antara Pengaturan dan Realisasi Tanggung Jawab Negara", Jurnal Hukum Positum, 4, no. 1 (2019): 45-46. doi: http://dx.doi.org/10.35706/positum.v4i1. and Nicken Sarwo Rini,"Analisis Implementasi Prinsip Non-Diskriminasi dalam Peraturan Daerah di Bidang Pendidikan dan Kesehatan", Jurnal HAM 9, no. 1 (2018): 28. doi: 10.30641/ham.2018.9.19-36.

28 Article 34 (2) of the 1945 Constitution of the Republic of Indonesia 
facilities. ${ }^{29}$ This indicates that Indonesia can be regarded as a civilized country that adopted internationally recognized human rights standards. ${ }^{30}$

Law No. 39 of 1999 concerning Human Rights (hereinafter, Human Rights Law) regulates several issues of the right to health. The basic provision places it as part of the right to life, determining that everyone has the right to life and to sustain life as well as to an adequate and healthy environment. ${ }^{31}$ Some other provisions are also implicitly related to the recognition of the right to health. This includes the right to grow and develop, ${ }^{32}$ the right to obtain communication and information (needed in relation to health);33 a series of women and children health rights ${ }^{34}$

Law No. 6 of 2018 concerning Health Quarantine ${ }^{35}$ was created by among others considers that Indonesia, as part of the world community, is committed to making efforts to prevent public health emergencies that troubling the world as mandated in international health regulation by fully respecting dignity, human rights, basics freedom, and its universal application. ${ }^{36}$ The law also covers the issue of the right to health. It guarantees the right for everyone to receive the same treatment in administering health quarantine and the right to obtain basic health services according to medical needs, food needs, and other daily life needs during the quarantine. ${ }^{37}$

Law 36 of 2009 concerning Health (hereinafter, Health Law) Article 1 No. 1 defines health as a healthy condition comprising all of physically, mentally, spiritually as well as social aspects that enable an individual to live productively both socially and economically. ${ }^{38}$ The Health Law explicitly recognizes that every person has the right to health, in the meaning a right to obtain health service from health service facilities in order to realize the highest degree of health. ${ }^{39}$ It acknowledges that every person has the same right to obtaining health resources access, the right to obtain safe, quality, affordable health services and the right to independently and responsibly

${ }^{29}$ Ibid., Article 34 (3)

${ }^{30}$ Insan Firdaus,"Pemenuhan Hak atas Kesehatan melalui Badan Penyelenggaran Jaminan Sosial Kesehatan di Indonesia", Jurnal HAM 5, no. 2 (2014): 122.

${ }^{31}$ Article 9 (1) and (3) of the Law No. 39 the Year 1999 concerning Human Rights

32 Ibid., Article 11

33 Ibid., Article 14 (1) and (2)

34 Ibid., Articles 49 (2) and (3), 52, 53 (1),54, Article 58 (1) and (2). 61, 62, 64, 65. See also Rico Mardiansyah, "Dinamika Politik dalam Pemenuhan Hak atas Kesehatan di Indonesia", Veritas et Justitia, 4, no. 1 (2018): 235.

35 This Law revoked and replaced Law No. 1 of 1962 concerning Sea Quarantine and Law No. 2 of 1962 concerning Air Quarantine according to Article 97 of Law No. 6 of 2018 concerning Health Quarantine

${ }^{36}$ Law No. 6 of 2018 concerning Health Quarantine, Consideration, letter c

37 Ibid., Article 7 and Article 8

38 Ibid., Article 1 No. 1

39 Ibid., Article 4 
determine the health services needed for themselves. ${ }^{40}$ Further, it recognizes that every person has the right to obtain a healthy environment to achieve the health standard. ${ }^{41}$ Moreover, every person has the right to gain balanced and responsible information and education regarding health. ${ }^{42}$ Lastly, every person has the right to gain information about their medical data including action and treatment that he/she has or will receive from the medical personnel. 43

In realizing the right to health, the efforts taken are health efforts as an integrated activity/series of activities with continuous manner maintaining and improving public health degree with disease prevention, improvement of health quality, disease treatment, and recovery of citizen health lead by the government and community, ${ }^{44}$ whether in the form of promotion, preventive, curative, rehabilitative and traditional health services.

As a reciprocal to the enjoyment of the right to health, the Health Law also imposes some obligations to every person, among others, to respect the right to health of other peoples, behave in a healthy life, and participate in social health insurance programs. ${ }^{45}$ Besides, the Health Law determines some government responsibilities for the availability of the environment, settings, health facilities, and resources, as well as access to information, education, and health service facilities. ${ }^{46}$

\subsection{The Legality of Covid-19 Countermeasures Action in Indonesia and the Reflection of the Right to Health}

The government had taken anticipatory steps for the transmission of the coronavirus by increasing alertness and preparedness at national entrances (airports, ports, and land crossing borders), especially those who have direct access to Wuhan or Peoples' Republic of China (PRC). In practice, officials at those entrances operate thermal scanner as early detection of symptoms of fever in incoming travelers. ${ }^{47}$ If anyone is indicated to be a potential suspect further examination is carried out and if necessary referred to a hospital. On 5 February 2020, Indonesia has imposed travel

40 Ibid., Article 5. See also Habib Shulton Asnawi \& Agus Setiawan, "Politik Hukum Perlindungan HAM di Indonesia (Studi Hak-hak Perempuan di Bidang Kesehatan", Jurnal Mahkamah: Kajian Ilmu Hukum dan Hukum Islam 2, no. 1 (2017): 90-91.

${ }^{41}$ Ibid.,Article 6

42 Ibid., Article 7

43 Ibid., Article 8

44 Ade Irawan Taufik,"Konsistensi Putusan Mahkamah Konstitusi dalam Pengujian beberapa Undang-undang terkait Kesehatan", Jurnal Konstitusi 16, no. 4 (2019): 774-775.

45 Articles 10, 11, and 13 of the Law No. 36 of 2009 concerning Health

46 Ibid., Articles 15, 16, and 17. See also Andrew Rosser, Litigating the Right to Health Courts, Politics, and Justice in Indonesia, (Hawaii: East-West Center, 2017), 6-7.

${ }^{47}$ Kementerian Kesehatan Republik Indonesia, Booklet tentang Novel Coronavirus (NCOV), Nomor 1, Edisi Februari (Jakarta: Kementerian Kesehatan Republik Indonesia, 2020). 
restrictions in the form of temporary suspension of flights to and from PRC. On March 5, 2020, Indonesia also imposed a ban on transit or entry into Indonesia for travelers who, in the last 14 days, came some suspected areas in Iran, Italy, and South Korea. Regarding public information on Covid-19 can be monitored through the Ministry of Health's website. ${ }^{48}$

The meaning of the right to health as previously described in Section 2.1. does not only to achieving the highest degree of health, but also to include physically, socially, mentally, and spiritually aspects. In an extraordinary situation like a global pandemics demands the presence of the state to take action in addressing the health problems of its citizens by adopting policies.

In order to measure the legality of Covid-19 action policies and countermeasures in Indonesia, Lawrence M. Friedman's legal system theory 49 may be used. The theory suggests three important components in an operating legal system, namely: ${ }^{0}$

1. Legal structure, It is parts that move in a mechanism. The structural component is associated with the Indonesian criminal justice system, thus including the structure of law enforcement institutions such as the police, prosecutors, courts, and correctional institutions.

2. Legal substance. It is the products of the legal system in the form of legal rules both written and unwritten. ${ }^{51}$

3. Legal culture is a human attitude towards law and the legal system of beliefs, values, thoughts, and expectations. In other words, legal culture is a state of social mind and social forces that determine how the law is used, avoided, or misused. 52

The next analysis will describe how Friedman theory on the relevance in measuring the legality of the Covid-19 countermeasures policy adopted by the National Government

${ }^{48}$ Kementerian Kesehatan Republik Indonesia, Booklet Pertanyaan dan Jawaban Terkait COVID-19, Nomor 2, Edisi Maret, (Jakarta: Kementerian Kesehatan Republik Indonesia, 2020). https://covid19.kemkes.go.id/qna-pertanyaan-dan-jawaban-terkaitCovid-19/

49 Anthon F. Susanto. Wajah Peradilan Kita, Konstruksi Sosial tentang Penyimpangan Mekanisme Kontrol dan Akuntabilitas Peradilan Pidana (Bandung: Refika Aditama, 2004), 58-59.

50 See Yuliana, Yuliana, "Dampak Pelaksanaan Hukuman Mati Terhadap Kondisi Kejiwaan Terpidana Mati di Indonesia," Indonesian Journal of Criminal Law Studies 1, no. 1 (2016): 48

${ }^{51}$ The government's actions are not only based on written law namely the law, but also unwritten law. See Zulkarnain Ridlwan, "Negara Hukum Indonesia Kebalikan Nachtwachterstaat," Fiat Justisia: Jurnal Ilmu Hukum 5 No.2 (2011): 147-148.

52 See Any Ismayawati, "Pengaruh Budaya Hukum terhadap Pembangunan Hukum di Indonesia: Kritik terhadap Lemahnya Budaya Hukum di Indonesia," Pranata Hukum 6 No. 1 (2011); 57, 61. "and Mella Ismelina FR, "Komunikasi Hukum dan Kepatuhan terhadap PSBB," Kompas.Com 22 April 2020. 


\subsubsection{In terms of the Legal Structure}

Some national legislation requires the readiness, awareness, and cooperation between the national government, regional governments, and society. Introduction part of the article has previously described some national agencies and sectoral ministries, in terms of executive powers, that play a pivotal role in dealing with the issues of Covid-19.

The Committee for the Handling of Covid-19 and National Economic Recovery in July 2020 was then established in order to accelerate the handling of Covid-19 as well as recovery and national economic transformation. ${ }^{53}$ The committee consists of Policy Committee, Covid-19 Handling Task Force; and National Economic Recovery and Transformation Task Force. ${ }^{54}$ In carrying out its duties, the committee may involve the ministry, institutions, agencies, local governments, business entities, experts, academics, and other parties as needed. 55 The creation of this committee seems related to the ideal of the national government that repeatedly mentions the term 'new normal era' to indicate the needs of all citizens to apply a new lifestyle that compatible with proper health protocol, and at the same time, begin to work step by step to regenerate the economics.

Law enforcement agencies have also involved in supporting the efforts to overcome legal and societal problems arises from the pandemic. The Chief of Indonesian Police has issued an edict to ensure the society's compliance with government policies with regards to the pandemic countermeasures, including the prohibition to organize community activities which cause a large mass gathering. 56 In terms of law enforcement, all police personnel is required to take necessary policy actions in accordance with the provisions of the applicable laws and regulations if find actions that are contrary to this edict. ${ }^{57}$ Those who do not obey the police's call to disperse themselves from the crowd will be charged with multiple provisions, namely Article 212, Article 216, and Article 218 of the Indonesian Criminal Code. 58

The office of the Prosecutor also takes action by Applying a short prosecutor examination for crimes as stipulated in the above Indonesian

${ }^{53}$ Article 1 (1) of the Presidential Regulation of the Republic Of Indonesia No. 82 of 2020 concerning the Creation of Committee for the Handling of COVID-19 and National Economic Recovery.

${ }^{54}$ Ibid., Article 2

${ }^{55}$ Ibid., Article 13

56 Edict of Chief of Police of the Republic of Indonesia No. : Mak/2/III/2020 concerning Compliance with the Government Policy in Handling the Spread of Corona Virus (Covid-19), para 2.a

57 Ibid., para 3.

58 Kompas.Com. "Tak Turuti Polisi Bubarkan Keramaian, Ini Ancaman Hukuman bagi Mereka yang Bandel", 23 March 2020, https://nasional.kompas.com/read/2020/03/23/ 15311191/tak-turuti-polisi-bubarkan-keramaian-ini-ancaman-hukuman-bagi-merekayang 
Criminal Core provisions, 59 but not limited to, the crime of deliberate swarming (intentional crowd). ${ }^{60}$ Besides, the Attorney General instructed his subordinates to make efforts, work, activities, and actions for early detection and early warning in the framework of prevention, deterrence, and mitigation of any nature of threats that may arise and threaten national interests and security in order to accelerate the handling of Covid-19, among others, by implementing the investigation/security/raising functions in accordance with the duties and functions of law enforcement intelligence. ${ }^{61}$ In the context of the legal proceedings, the Supreme Court issued a circular that guidelines the use of e-court application in the administration of trials and the application of e-litigation in the conduct of trials. 62

\subsubsection{In terms of the substance of the law}

As previously described, several national legal instruments have been sought at the level of the Constitution, laws, and implementing regulations and technical regulations related to a reflection of the right to health. Specifically, concerning the action of handling Covid-19 at least it can refer to a number of the following arrangements:

For decades, Indonesian legislations on health were created incompatible to international health standards. As an example, Law No. 6 of 1962 concerning Plague (hereinafter, Law on Plague) adopted the meaning of plague as stipulated in the 1961 International Sanitary Regulation concerning epidemic. ${ }^{63}$ In 1968, Law on Plague was later ammended by Law No. 7 of 1968, classified the Para-cholera El Tor into quarantine diseases by considering the World Health Assembly's Decision in the XV Session regarding cholera (WHO XV Resolution 1962 No. 38). ${ }^{64}$

59 Instruction of Attorney General of the Republic of Indonesia No. 5 of 2020 Concerning Policy for Implementating the Tasks and Case Handling during the Prevention of Covid-19 Spread, Second Dictum para 8 .c

${ }^{60}$ Letter of Attorney General of the Republic of Indonesia No. B-049 / A / SUJA / 03/2020 IN 2020 Concerning Optimization of the Implementation of Assignments, Functions, and Authority during the Efforts to Prevent the Spread of Covid-19, addressed to all Chief of High Prosecutor's office, dated 27 March 2020, para 3.

61 Instruction of Attorney General of the Republic of Indonesia No. 5 of 2020 Concerning Policy for Implementating the Tasks and Case Handling during the Prevention of Covid-19 Spread, Second Dictum para 4.b

62 Circular of the Supreme Court of the Republic of Indonesia No. 1 of 2020 Concerning Guidelines of the Implementation of the Task During the Prevention of Corona Virus Disease 2019 (Covid - 19) in the Supreme Court and its Judiciaries, para 1. b and 2.e

63 Explanation of Article 2 of the Law No. 6 of 1962 concerning Plague

${ }^{64}$ Law No. 7 of 1968 concerning amendment of Article 3 of the Law No. 3 of 1962 concerning Plague, First Dictum. See also WHA15.38 Committee on International Quarantine in which the Fifteenth World Health Assembly considered the relationship, under the International Sanitary Regulations, between El Tor infection and classical cholera. Official Records of the World Health Organization No. 118, Fifteenth World Health Assembly 
Law No. 4 of 1984 concerning Infectious Disease (hereinafter, Law on Infectious Diseases) was created to revoke and replace Law on Plague and its amendment. The Elucidation of this Law reflects the idea behind as well as the direction to be achieved by the Law. It, among others, explains that the rapid development of technology and science will affect the environment, way of life, and the development of patterns of disease including diseases that can cause epidemics; thus a type of disease that was not originally a problem can be a problem or vice versa. Disease patterns can be influenced by developments in international traffic and environmental changes. ${ }^{65}$ Law on Infectious Diseases authorizes the Minister of Health to determine certain types of diseases that can cause epidemics and to determine certain areas within the territory of Indonesia that have been affected by the plague as the area of the plague. ${ }^{66}$ The Law also determines that epidemic countermeasures include epidemiological investigations; examination, treatment, care, and isolation of patients, including quarantine measures; prevention and immunization; annihilation of the cause of the disease; handling of corpses due to outbreaks; public education; and other forms of countermeasures. ${ }^{67}$ The above countermeasures shall be implemented by taking into account environmental sustainability and involve community participation actively. 68

Health Law determines that national and regional governments ensure and provide facilities for preventing diseases to avoid or reduce the risks, problems, and adverse effects of the disease. ${ }^{69}$ Specifically, this law also covers the issue of infectious diseases. It outlines the responsibility of the national government, regional government, and the community for the prevention, control, and eradication of infectious diseases as well as their consequences. 70 The national government and regional governments periodically determine and the types and spread of potentially infectious and/or infectious diseases in a short period, and mentions areas that can be a source of transmission, may conduct surveillance of infectious diseases and determine the types of diseases that require quarantine, quarantine place, and quarantine duration. ${ }^{71}$ The Government, in carrying out efforts to prevent, control and eradicate infectious diseases, may declare an area is in an epidemic or extraordinary occurrence by taking into account a reliable

Geneva, 8 - 25 May 1962, Part I Resolutions and Decisions Annexes, World Health Organization, Geneva, September 1962

${ }^{65}$ Law No. 4 of 1984 concerning Infectious Disease, Elucidation, Part I, para 4.

66 Ibid., Article 3 and Article 4

67 Ibid., Article 5 (1)

68 Ibid., Article 5 (2) and 6 (1)

${ }^{69}$ Article 62 (2) and (3) of the Law No. 36 of 2009 concerning Health

70 Ibid., Article 152 (1)

71 Ibid., Article 154 and Article 155 
research results. ${ }^{72}$ In the implementation of the control of infectious diseases, authorized health personnel can inspect places where suspected vector and other disease sources are developing/proliferating. ${ }^{73}$

In terms of legal substance, Law No. 27 of 2007 concerning Disaster Management (Law of Disaster Management) can classify the spread of Covid19 as a non-natural disaster. ${ }^{74}$ This law determines that The government and regional government are responsible for the implementation of disaster management that consists of 3 stages, namely pre-disaster; emergency response period; and post-disaster. ${ }^{75}$ The Law of Health Quarantine was then used as a legal basis by the President to issue a decree that stipulating the pandemic Covid-19 as a public health emergency. 76 The national government also created regulation to provide a legal basis for establishing a large-scale social restriction. ${ }^{77}$ Some technical regulations include the substance of infectious disease handling. As an example, the Regulation of Minister of Health No. 82 of 2014 concerning the Management of Infectious Diseases determines that Infectious Disease Management is carried out through public health efforts and individual health efforts. ${ }^{78}$ The regulation also distinguishes the target of infectious disease management programs based on the prevalence/incidence of illness and infectious disease characteristics, including reduction, elimination, and/or eradication. ${ }^{79}$

\subsubsection{In terms of legal culture}

Some laws and regulations put community involvement as an important aspect to address the plague. The Health Law acknowledges the community participation, both individually and organized, in all forms and stages of health development to accelerate the achievement of the highest degree of public health, which includes active and creative participation. 80 Basically, everyone can participate in the prevention of epidemics in the form of providing power, expertise, fund other types of assistance that are carried out by informing the presence of patients or suspects of plague sufferers, helping the smooth the implementation of pandemic

72 Ibid., Article 156 (1) and (2)

73 Ibid., Article 157 (2)

74 Article 1 (3) of the Law No. 27 of 2007 concerning Disaster Management

75 Ibid., Article 5 and 33

76 Decree of the President of the Republic of Indonesia No. 11 of 2020 concerning the Stipulation of Coronavirus Disease (Covid-19) as Public Health Emergency

77 Government Regulation No. 21 of 2020 concerning Large-Scale Social Restrictions in the Framework of Accelerating Handling of Covid-19

78 Article 5 (2) of Regulation No. 82 of 2014 concerning the Management of Infectious

79 Ibid., Article 8 (1)

80 Article 174 of Law No. 36 of 2009 concerning Health 
countermeasures, stimulating community motivation in joining the countermeasure efforts, and other activities. ${ }^{81}$

Facts in society indicate that there have been many violations of the rules that are applied for the pandemic situation. Despite the massive daily based-public information regarding the catastrophic resulted from the spread of Covid-19, not all peoples are comply to laws and regulations in handling the pandemic. The government decided not to apply a lock-down policy as practiced in various countries opens the opportunity for some peoples to do daily activities. Therefore, preventive-curative measures are needed.

The creation of technical policies, decrees, and regulations that refer to health surveillance may consider social, economic, and cultural situations of the community. ${ }^{82}$ This will ensure that those law products reflect the real life of the society. Related to the regulation of large-scale social restrictions, the expected direction of the construction of legal culture is the existence of community compliance as a legal objective. ${ }^{83}$ Experts also argue that a weak culture of obeying laws/rules in the community can extend the handling period of the Covid-19. The legal culture is related to public observance and firmness of the authorities. ${ }^{84}$ There is also an expert who considers that the legal awareness of the public to comply with social restrictions on a large scale becomes important because these restrictions do not have criminal implications or sanctions that are coercive. The concept of legal awareness, which is related to the theory of legal culture, conceives the awareness to act in accordance with the provisions of the law, so it is a bridge that connects regulations with the legal behavior of community members. Thus, no matter how good the rules that are made if it is not supported by the legal awareness of the community it will be not very useful. 85

Theoretically, the legal culture of a community depends on the legal culture of its members which is influenced by their educational background, environment, culture, position, and even interests. ${ }^{86}$ Legal culture contains components of values and attitudes that put it within the cultural framework of society so that it is crucial for the operation of law in society. ${ }^{87}$

81 Article 21 and 22 of The Government Regulation No. 40 of 1991 concerning the Control of Communicable Disease

82 Article 6 (1), 7(1) and (2)(a) of the Regulation of Minister of Health No. 45 of 2014 regarding Health Surveillance Implementation.

83 Mella Ismelina FR, loc.cit.

84 See for example statement by Abdul Hakim Siagian as cited in Pemerintah Provinsi Sumatera Utara, Budaya Taat Hukum Lemah Bisa Perpanjang Masa Penanganan Covid-19, 20 April 2020. https://www.sumutprov.go.id/artikel/artikel/budaya-taat-hukum- lemahbisa-perpanjang-masa-penanganan-covid19

85 Septa Candra, PSBB dan Kesadaran Hukum Masyarakat, Kolom Hukum Online, 8 May 2020, https://www.hukumonline.com/berita/baca/lt5eb5002b36e77/psbb-dankesadaran-hukum-masyarakat-oleh--septa-candra

86 Any Ismayanti, op.cit., 61

87 Mella Ismelina FR, loc.cit. 
Therefore, the theory of legal culture can explain why a series of rules issued to handling the pandemic is not fully obeyed by the peoples in Indonesia.

\section{Conclusion}

Based on the results and discussions above, there are several conclusions as follows:

1. The right to health meaning is holistic, not only includes the achievement of the highest degree of health but also how health is measured both physically, socially, mentally, and spiritually. The right to health has been classified as a constitutional right, following its stipulation in the 1945 Constitution of the Republic of Indonesia. It is also enshrined in some legislations, among others Law No. 39 of 1999 concerning Human Rights, Law No. 6 of 2018 concerning Health Quarantine, and Law 36 of 2009 concerning Health. This reflects the presence of the state to interfere with the health problems of its citizens.

2. The three theoretical components in the operating legal system, namely legal structure, legal substance, and legal culture are used to assess the legality of Covid-19 countermeasures action in Indonesia. In terms of the substance of the law, a set of statutory laws applied for the pandemic countermeasures has been in line with the meaning and reflection of the right to health. This article found a synergy between relevant agencies authorities when conducting efforts to counter measuring Covid-19, reflecting a workable legal structure. The component of legal culture seems to need to be addressed, following the disobeying of a part of society, that indicates their unreadily and unconsciously to participate and to involve in the response to Covid-19. Therefore, it is necessary to pursue their participatory, preventive, and high awareness measures.

\section{Books}

\section{BIBLIOGRAPHY}

Bahar, Saafroedin, et.al. Risalah Sidang BPUPKI dan PPKI. Jakarta: Sekretariat Negara, 1995.

Rosser, Andrew. Litigating the Right to Health Courts, Politics, and Justice in Indonesia. Hawaii: East-West Center, 2017.

Susanto, Anthon F. Wajah Peradilan Kita, Konstruksi Sosial tentang Penyimpangan Mekanisme Kontrol dan Akuntabilitas Peradilan Pidana. Bandung: Refika Aditama, 2004.

United Nations. Economic, Social and Cultural Rights Handbook for National Human Rights Institutions. New York and Geneva: United Nations Publication, 2005. 


\section{Journal Articles}

Affandi, Hernadi. "Implementasi Hak atas Kesehatan menurut Undangundang Dasar 1945: antara Pengaturan dan Realisasi Tanggung Jawab Negara." Jurnal Hukum Positum 4, no. 1 (2019): 39-50. https://doi.org/10.35706/positum.v5i1

Alfitri, Alfitri. "Ideologi Welfare State dalam Dasar Negara Indonesia: Analisis Putusan Mahkamah Konstitusi Terkait Sistem Jaminan Sosial Nasional." Jurnal Konstitusi 9, no.3 (2012): 449- 472

Anggriawan Wisadha, Made Adhitya, and Grita Anindarini Widyaningsih. "Human Rights and the Environmental Protection: The Naïveté in Environmental Culture" Udayana Journal of Law and Culture 2, no. 1 (2018): 73-96. https://doi.org/10.24843/UJLC.2018.v02.i01.p04

Asnawi, Habib Shulton \& Agus Setiawan."Politik Hukum Perlindungan HAM di Indonesia (Studi Hak-hak Perempuan di Bidang Kesehatan." Jurnal Mahkamah: Kajian Ilmu Hukum dan Hukum Islam 2, no. 1 (2017): 77102. https://doi.org/10.25217/jm.v2i1.139

Cornescu, Adrian Vasile. "The Generations of Human's Rights." Dny práva2009 - Days of Law: the Conference Proceedings, 1. edition. Brno : Masaryk University, 2009.

Domaradzki, Spasimir, Margaryta Khvostova, and David Pupovac. "Karel Vasak's "Generations of Rights and the Contemporary Human Rights Discourse." Human Rights Review 20 (2019): 423-443. https://doi.org/10.1007/s12142-019-00565-x

Firdaus, Firdaus. "Pemenuhan Hak atas Kesehatan bagi Penyandang Skizofrenia di Daerah Istimewa Yogyakarta." Jurnal Ilmiah Kebijakan Hukum 10, no. 1 (2016): 87-103.

Firdaus, Insan. "Pemenuhan Hak atas Kesehatan melalui Badan Penyelenggaran Jaminan Sosial Kesehatan di Indonesia." Jurnal HAM 5, no. 2 (2014): 117-128.

Hadiprayitno, Irene Istiningsih. "Defensive enforcement: Human rights in Indonesia" Human Rights Review 11, no. 3 (2010): 373-399. https://doi.org/10.1007/s12142-009-0143-1

I Gede Yusa and Bagus Hermanto."Implementasi Green Constitution di Indonesia: Jaminan Hak Konstitusional Pembangunan Lingkungan Hidup Berkelanjutan.” Jurnal Konstitusi 15, no. 2 (2018): 306-326. https://doi.org/10.31078/ik1524

Ismayawati, Any. "Pengaruh Budaya Hukum terhadap Pembangunan Hukum di Indonesia: Kritik terhadap Lemahnya Budaya Hukum di Indonesia." Pranata Hukum 6 no.1 (2011); 55-68

Mardiansyah, Rico. "Dinamika Politik dalam Pemenuhan Hak atas Kesehatan di Indonesia", Veritas et Justitia, 4, no. 1 (2018): 227251.https://doi.org/10.25123/vej.2918

Petroski, Karen. "Legal fictions and the Limits of Legal Language." International Journal of Law in Context 9, no. 4 (2013): 485-505. https://doi.org/10.1017/S1744552313000268

Ridlwan, Zulkarnain. "Negara Hukum Indonesia Kebalikan Nachtwachterstaat." Fiat Justisia: Jurnal Mmu Hukum 5, no. 2 (2011): 141-152. https://doi.org/10.25041/fiatjustisia.v5no2.56 
Rini, Nicken Sarwo,"Analisis Implementasi Prinsip Non-Diskriminasi dalam Peraturan Daerah di Bidang Pendidikan dan Kesehatan", Jurnal HAM 9, no. 1 (2018): 19-36. http://dx.doi.org/10.30641/ham.2018.9.19$\underline{36}$

Sonata, Depri Liber. "Metode Penelitian Hukum Normatif dan Empiris: Karakteristik Khas dari Metode Meneliti Hukum." Fiat Justisia: Jurnal Ilmu Hukum, 8, no. 1 (2014): https: / / doi.org/ 10.25041/fiatjustisia.v8no1.283

Taufik, Ade Irawan. "Konsistensi Putusan Mahkamah Konstitusi dalam Pengujian beberapa Undang-undang terkait Kesehatan." Jurnal $\begin{array}{lllll}\text { Konstitusi } & 16, & \text { no. } & 4 & \text { (2019): }\end{array}$ https://doi.org/10.31078/jk1645

Yuliana, Yuliana. "Dampak Pelaksanaan Hukuman Mati Terhadap Kondisi Kejiwaan Terpidana Mati di Indonesia." Indonesian Journal of Criminal Law Studies 1, no. 1 (2016): 45-54

\section{Law and Regulation of the Republic of Indonesia}

The 1945 Constitution of the Republic of Indonesia

Law No. 1 of 1962 concerning Sea Quarantine

Law No. 2 of 1962 concerning Air Quarantine

Law No. 6 of 1962 concerning Plague

Law No. 7 of 1968 concerning the amendment of Article 3 of the Law No. 3 of 1962 concerning Plague

Law No. 4 of 1984 concerning Infectious Disease

Law No. 39 the Year 1999 concerning Human Rights

Law No. 27 of 2007 concerning Disaster Management

Law 36 of 2009 concerning Health

Law No. 6 of 2018 concerning Health Quarantine

Presidential Regulation No. 82 of 2020 concerning the Creation of Committee for the Handling of COVID-19 and National Economic Recovery

Decree of the President of the Republic of Indonesia No. 7 of 2020 concerning Task Force for the Acceleration of Covid-19 Handling

Decree of the President of the Republic of Indonesia No. 11 of 2020 concerning the Stipulation of Coronavirus Disease (Covid-19) as Public Health Emergency

Government Regulation No. 40 of 1991 concerning the Control of Communicable Disease

Government Regulation No. 21 of 2020 concerning Large-Scale Social Restrictions in the Framework of Accelerating Handling of Covid-19

Regulation of Minister of Health No. 45 of 2014 regarding Health Surveillance Implementation.

Regulation of Minister of Health No. 82 of 2014 concerning the Management of Infectious

Regulation of Minister of Law and Human Rights No. 7 of 2020 concerning the Granting of Visa and Residence Permit in the Efforts of Preventing the Coronavirus Entry 
Regulation of Minister of Law and Human Rights No. 11 of 2020 concerning Temporary Prohibition of Foreigners Entering the Territory of the Republic of Indonesia

Decree No. HK.01.07/Menkes/169/2020 concerning the Establishment of a Reference Hospital for the Prevention of Certain Emerging Infection Diseases.

Decree of the Minister of Health of the Republic of Indonesia No. HK.01.07/ MENKES/413/2020 concerning Guidelines for Prevention and Control Coronavirus Disease 2019 (COVID-19)

Circular Letter of Minister of Health No. No. HK.02.01/Menkes/199/2020 concerning the Communication of Covid-19 Handling

Circular of Minister of Health No. HK.02.01/Menkes/202/2020 concerning the Self-Isolation Protocol in Handling Corona Virus Disease (Covid19)

Circular of Minister of Religious Affairs No: SE. 15 of 2020 Regarding Guidelines for the Management of Religious Activities in House of Worship in Realizing Productive Communities and Safe During the Pandemic Period.

Circular of the Supreme Court of the Republic of Indonesia No. 1 of 2020 Concerning Guidelines of the Implementation of the Task During the Prevention of Corona Virus Disease 2019 (Covid - 19) in the Supreme Court and its Judiciaries

Instruction of Attorney General of the Republic of Indonesia No. 5 of 2020 Concerning Policy for Implementing the Tasks and Case Handling during the Prevention of Covid-19 Spread

Letter of Attorney General of the Republic of Indonesia No. B-049 / A / SUJA / 03/2020 IN 2020 Concerning Optimization of the Implementation of Assignments, Functions, and Authority during the Efforts to Prevent the Spread of Covid-19, addressed to all Chief of High Prosecutor's office, dated 27 March 2020

Edict of Chief of Police of the Republic of Indonesia No. : Mak/2/III/2020 concerning Compliance with the Government Policy in Handling the Spread of Corona Virus (Covid-19), para 2.a

Circular of Director General of Disease Prevention and Control No. SR.03.04/II/55/2020 concerning Preparedness for the Spread of Pneumonia from the People's Republic of China to Indonesia, dated 6 January 2020.

Circular of Director General of Health Services No. YR.01.02/111/0027/2020 concerning Hospital Preparedness in Handling Emerging Infectious Diseases, dated 7 January 2020.

Circular of Director General of Disease Prevention and Control SR.02.02/II/270/2020 concerning Preparedness Guidelines for Coronavirus Novel Infection (2019-nCoV), dated 28 January 2020.

Circular of Director General of Disease Prevention and Control HK.02.02 / II / 329/2020 concerning Increased Awareness of 2019-nCoV Infection as a World Public Health Emergency (KKMMD) / PHEIC, dated 31 January 2020. 


\section{Other Document}

Eliza, Pocut et.al., Laporan Akhir Kelompok Kerja Analisis Evaluasi Hukum mengenai Pemenuhan Hak Kesehatan. Jakarta: Pusat Analisis dan Evaluasi Hukum Nasional Badan Pembinaan Hukum Nasional Kementerian Hukum dan HAM RI, 2017.

Kementerian Kesehatan Republik Indonesia, Booklet tentang Novel Coronavirus (NCOV), Nomor 1, Edisi Februari, (Jakarta: Kementerian Kesehatan Republik Indonesia, 2020).

Kementerian Kesehatan Republik Indonesia, Booklet Pertanyaan dan Jawaban Terkait COVID-19, Nomor 2, Edisi Maret, (Jakarta: Kementerian Kesehatan Republik Indonesia, 2020).

United Nations Economic and Social Council UN doc. E/CN.4/1987/17, Annex, Limburg Principles on the Implementation of the International Covenant on Economic, Social, and Cultural Rights

WHA15.38 Committee on International Quarantine in which the Fifteenth World Health Assembly considered the relationship, under the International Sanitary Regulations, between El Tor infection and classical cholera. Official Records of the World Health Organization No. 118, Fifteenth World Health Assembly Geneva, 8 - 25 May 1962, Part I Resolutions and Decisions Annexes, World Health Organization, Geneva, September 1962

\section{Website Content}

Mella Ismelina FR. "Komunikasi Hukum dan Kepatuhan terhadap PSBB." Kompas.Com 22 April 2020. https://nasional.kompas.com/read/2020/04/22/ 19272571 /komunikasi-hukum-dan-kepatuhan-terhadappsbb?page $=$ all.

Kompas.Com. "Tak Turuti Polisi Bubarkan Keramaian, Ini Ancaman Hukuman bagi Mereka yang Bandel", 23 March 2020, https://nasional.kompas.com/read/2020/03/23/ 15311191/takturuti-polisi-bubarkan-keramaian-ini-ancaman-hukuman-bagimereka-yang

Pemerintah Provinsi Sumatera Utara "Budaya Taat Hukum Lemah Bisa Perpanjang Masa Penanganan Covid-19.” 20 April 2020. https://www.sumutprov.go.id/artikel/artikel/budaya-taat-hukumlemah-bisa-perpanjang-masa-penanganan-covid19

Septa Candra. "PSBB dan Kesadaran Hukum Masyarakat." Kolom Hukum Online, 8 May 2020, https://www.hukumonline.com/berita/baca/lt5eb5002b36e77/psbbdan-kesadaran-hukum-masyarakat-oleh--septa-candra 